\title{
PEMBERIAN MANAJEMEN STRES PASKA BANJIR SEBAGAI UPAYA MENINGKATKAN KESEHATAN JIWA MASYARAKAT PAKU ALAM KECAMATAN SUNGAI TABUK KABUPATEN BANJAR
}

\author{
Subhannur Rahman ${ }^{*}$, Mohammad Basit' ${ }^{2}$, Rian Tasalim $^{3}$, Rifa'atul Mahmudah ${ }^{4}$ \\ 1,2,3,4 Program Studi Sarjana Keperawatan dan Profesi Ners, Fakultas Kesehatan, \\ Universitas Sari Mulia Banjarmasin \\ *e-mail :zikrisubhan55@gmail.com
}

\begin{abstract}
ABSTRAK
Bencana banjir merupakan salah satu bencana alam yang dapat mengakibatkan berbagai macam dampak masalah kesehatan, baik masalah fisik ataupun masalah kejiwaan pada setiap orang. Timbulnya masalah kesehatan jiwa bisa disebabkan karena adanya trauma tersendiri dan berkepanjangan dari para penyintas yang pernah berada dikondisi bencana banjir. Berdasarkan hasil survey yang dilakukan di Desa Paku Alam Kecamatan Sungai Tabuk didapatkan data bahwa sebagian besar masyarakat disana mengalami stres, kecemasan, depresi bahkan sampai dengan PTSD (Post Trauma Stress Disorder). Upaya promosi kesehatan jiwa yang dilakukan pemerintah belum maksimal menjangkau masyarakat yang ada di Desa Paku Alam Kecematan Sungai Tabuk Kabupaten Banjar. Hal ini dibuktikan dengan belum adanya kader kesehatan jiwa di Desa Paku Alam. Pelayanan kesehatan jiwa masih berfokus pada upaya kuratif seperti rujukan pasien yang mengalami masalah kesehatan jiwa. Apabila upaya promotif dan preventif kesehatan jiwa tidak segera dilakukan maka angka masalah kejiwaan dan gangguan jiwa dapat meningkat di Desa tersebut. Salah satu upaya yang dapat dilakukan untuk memelihara, menjaga dan meningkatkan kesehatan jiwa paska bencana banjir adalah dengan cara mengelola stres atau manajemen stres. Manajemen stres adalah salah satu upaya dimana individu melakukan pengontrolan atau pengaturan stres. Tujuannnya agar masyarakat Desa Paku Alam mengenal penyebab stres dan mengetahui tehniktehnik mengelola stres, sehingga lebih baik dalam menguasai stres dalam kehidupan, dan pada akhirnya kondisi sehat mental dapat dicapai secara optimal.
\end{abstract}

Kata Kunci : Kesehatan Jiwa, Manajemen Stres, Paska Banjir.

\section{A. PENDAHULUAN}

Indonesia sering disebut sebagai negara kepulauan yang secara geografis merupakan negara yang rawan terjadinya bencana alam. Hampir di sepanjang tahun sering kita mendengar berita tentang berbagai kejadian bencana alam yang terjadi. Selain itu, Indonesia juga merupakan negara tropis yang memiliki dua musim yaitu kemarau dan penghujan. Saat musin penghujan banyak daerah yang mengalami bencana besar seperti longsor dan banjir (Taufiq et al., 2014., Gladis et al., 2020).

Salah satu kawasan desa yang rentan dengan kondisi banjir besar adalah Desa Paku Alam Kecamatan Sungai Tabuk 
kabupaten Banjar. Besarnya dampak yang ditimbulkan hampir melumpuhkan segala aktivitas masyarakat setempat, banyaknya jalan yang terendam, rusaknya fasilitas umum dan permukiman warga serta munculnya permasalahan kesehatan membuat masyarakat disana merasakan trauma yang mendalam.

Dalam setiap peristiwa bencana, dampak buruk yang ditimbulkan dari insiden kritis, psikologis selalu dibutuhkan dan diarahkan pada upaya meminimalisir dampak yang mungkin muncul dari bencana. Pada kasus-kasus insiden kritis yang ringan, seseorang mungkin bisa pulih dengan cepat dari peristiwa yang dialami. Namun pada kasus-kasus tertentu, terutama yang melibatkan kehilangan, seseorang terkadang membutuhkan bantuan untuk memulai kehidupannya kembali.

Menurut Parker et al (2016) menyebutkan bahwa dampak dari bencana alam terhadap kesehatan mental manusia dewasa bisa menyebabkan terjadinya PTSD, depresi, gangguan kecemasan, gangguan penyesuaian. Hal ini sebagaimana juga dijelaskan oleh Ehreinreich (2001) dalam penelitian Taufiq et al (2014) beberapa kondisi yang berpengaruh besar terhadap kerentanan seseorang sehingga beresiko mengalami permasalahan psikologis adalah semakin tinggi tingkat keparahan bencana dan kengerian pengalaman yang dialami maka semakin tinggi pula efek psikologis yang dirasakan.

Permasalahan psikologis yang dirasakan oleh masyarakat Desa Paku Alam pasca bencana banjir sangatlah kompleks, adanya rasa kesedihan akibat kehilangan harta benda, ketakutan, rasa cemas yang dirasakan dan kurangnya penghasilan selama dipengungsian membuat masalah tersebut menjadi lebih kompleks dan membuat rasa trauma secara psikologis yang begitu besar. Meskipun seseorang telah sama-sama mengalami kejadian bencana yang serupa, namun respon yang dirasakan setiap individu pastilah berbeda-beda. Ada yang dalam ketegori berat, ringan dan ada pula orang yang tidak mengalami trauma sama sekali, hal ini tergantung pada kapasitas masing-masing orang dalam menilai dan mengatasi stresor yang dihadapi (Mendatu, 2010).

Mengingat besarnya dampak yang ditimbulkan oleh bencana banjir yang hakikatnya adalah sumber stres yang berujung kepada permasalahan psikologis maka perlu suatu upaya yang menyeluruh 
dalam penyelenggaraan penanggulangan bencana baik saat sedang terjadi bencana ataupun setelah bencana berakhir. Upaya promosi kesehatan jiwa yang dilakukan pemerintah belum maksimal menjangkau masyarakat yang ada di Desa Paku Alam Kecematan Sungai Tabuk Kabupaten Banjar.

Hal ini dibuktikan dengan belum adanya kader kesehatan jiwa di Desa Paku Alam. Pelayanan kesehatan jiwa masih berfokus pada upaya kuratif seperti rujukan pasien yang mengalami masalah kesehatan jiwa. Apabila upaya promotif dan preventif kesehatan jiwa tidak segera dilakukan maka angka masalah kejiwaan dan gangguan jiwa dapat meningkat di Desa tersebut. Salah satu upaya yang dapat dilakukan untuk memelihara, menjaga dan meningkatkan kesehatan jiwa paska bencana banjir adalah dengan cara mengelola stres atau manajemen stres. Manajemen stres adalah salah satu upaya dimana individu melakukan pengontrolan atau pengaturan stres. Tujuannnya agar masyarakat Desa Paku Alam mengenal penyebab stres dan mengetahui tehnik-tehnik mengelola stres, sehingga lebih baik dalam menguasai stres dalam kehidupan, dan pada akhirnya kondisi sehat mental dapat dicapai secara optimal.

\section{Gambar 1.1 Lokasi Pengabdian Masyarakat}
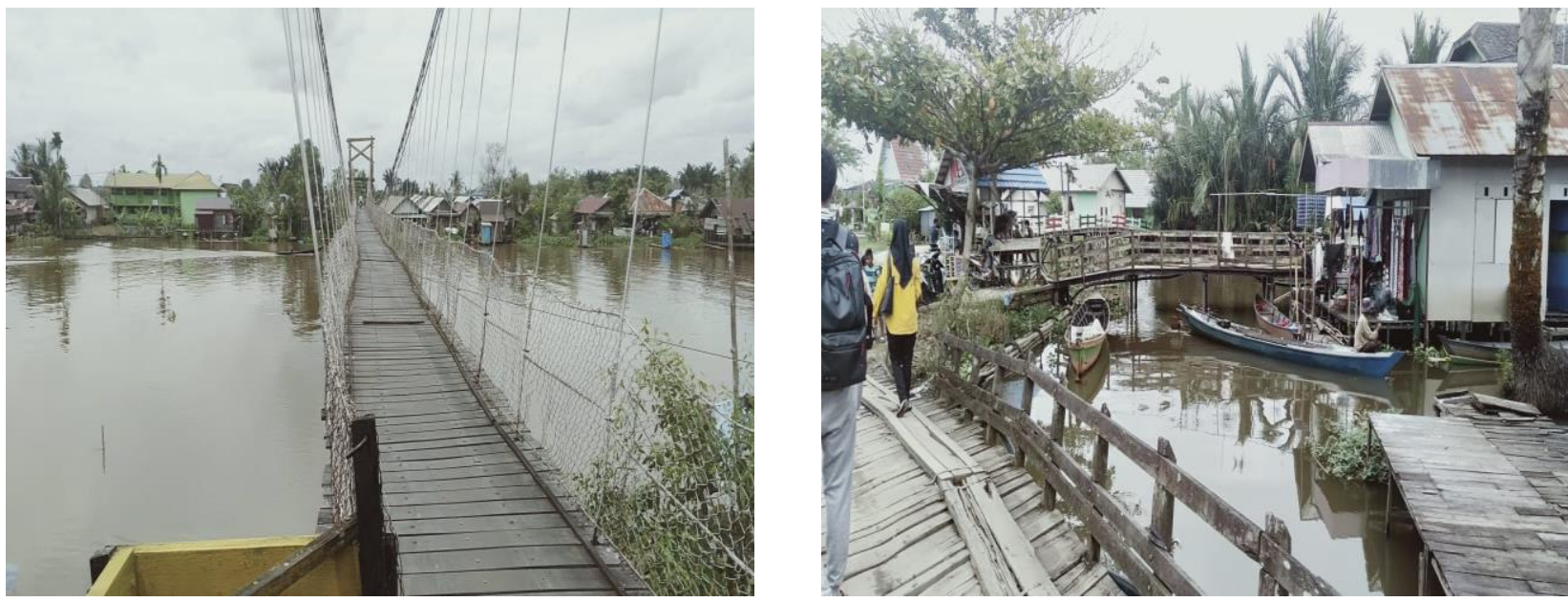


\section{B. METODE}

Adapaun solusi yang ditawarkan kepada mitra adalah metode pengelolaan stres paska banjir sebagai berikut:

1. Masyarakat yang ada di Desa Paku Alam diajarkan untuk mengkaji tanda dan gejala stres yang dialami menggunakan kuesioner Self Repoting Questionnaire-29 (SRQ-29).

2. Masyarakat yang ada di Desa Paku Alam diberikan pendidikan kesehatan atau penyuluhan tentang stres dan cara mengelola stres paska banjir

3. Masyarakat yang ada di Desa Paku Alam diberikan pelatihan tentang cara mengelola stres paska banjir. Adapaun tehnik manajemen stres yang akan diajarkan kepada masyarakat yang ada di Masyarakat yang ada di Desa Paku Alam antara lain:

a. Latihan nafas dalam

Latihan nafas dalam dilakukan dengan cara mengambil posis yang nyaman bisa duduk atau tiduran, tutup mata, Tarik nafas dalam dari hidung ditahan sebentar (3-5 detik) kemudian hembuskan udara perlahan-lahan dari mulut, ulangi 4 sampai 5 kali, evaluasi manfaatnya, dan latih secara rutin 3 sampai 4 kali sehari. b. Latihan relaksasi otot progresif Relaksasi otot progresif adalah latihan mengencangkan dan mengendorkan otot sambal nafas dalam pada otot muka sampai dengan kaki.

c. Latihan berfokus pada lima jari Latihan berfokus pada lima jari dikenal juga dengan hipnotis lima jari, pasien diminta memfokuskan pandangan dan pikiran pada ke lima jari (jari jempol bertemu dengan jari telunjuk, jari jempol bertemu dengan jari tengah, jari jempok bertemu dengan jari manis dan jari jempol bertemu dengan jarik kelingking), tarik nafas dalam, rileks dan kosongkan pikiran.

d. Penghentian pikiran Setiap kali muncul pikiran yang mengganggu dan tak dapat mengendalikannya, maka dapat dilakukan penghentian pikiran dengan mengatakan stop.

e. Membangun spiritual positif Melaksanakan ibadah bersama di rumah dengansemua anggota keluarga. Berdoa untuk diri sendiri dan keluarga, masyarakat, tenaga kesehatan dan pemerintah, senantiasa membaca kitab suci dan 
perbanyak membaca buku-buku agama acuan untuk pelaksanaan kegiatan manajemen stres paska bencana.

4. Masyarakat yang ada di Desa Paku

Alam diberikan buku pedoman sebagai

Gambar 1.2 Proses Pengabdian Masyarakat
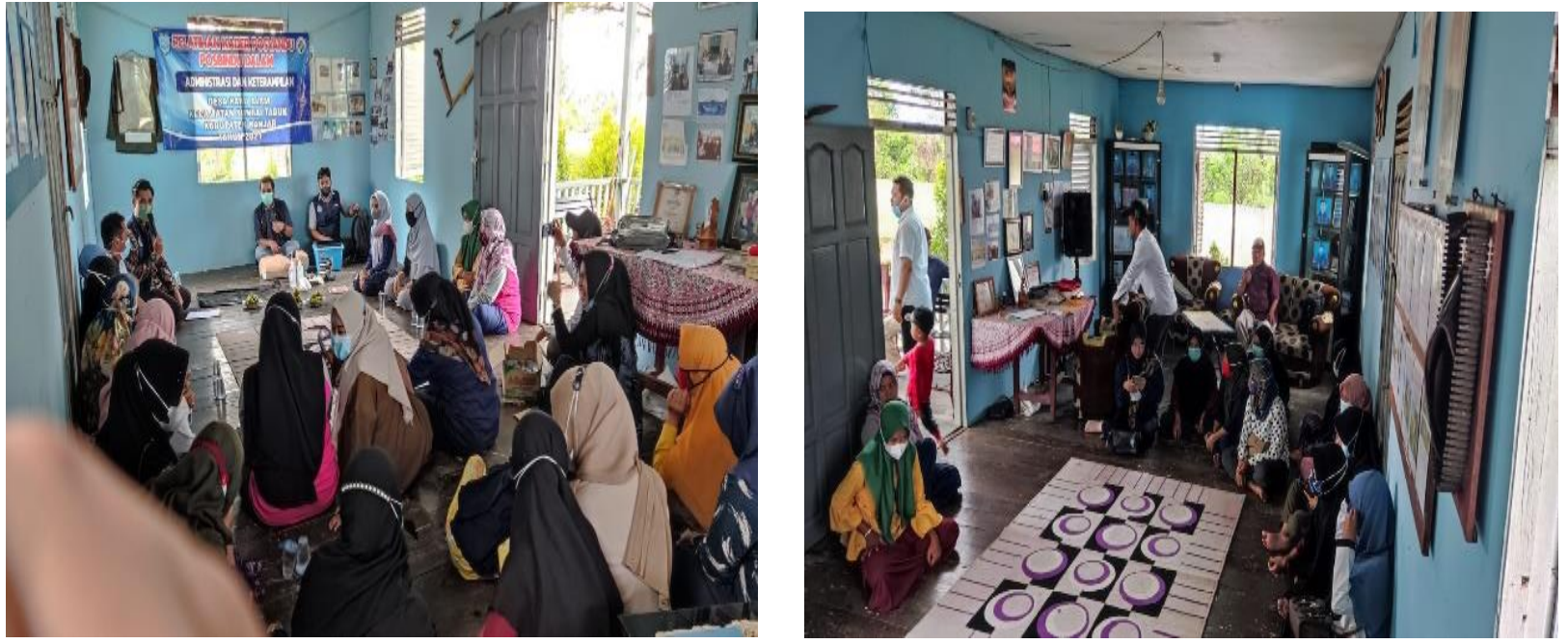

\section{HASIL DAN PEMBAHASAN}

Hasil yang dicapai dalam pelaksaan kegiatan pengabdian kepada masyarakat ini adalah sebagai berikut :

1. Kegiatan ini merupakan tahap awal dengan pemerintah desa setempat dalam hal ini Kepala Desa Paku Alam dan Kepala Puskemas Sungai Tabuk 2. Setelah mendapatkan ijin dan persetujuan dengan Kepala Desa Paku Alam dan Kepala Puskemas Sungai

Tabuk 2, maka selanjutnya tim melakukan koordinasi dengan salah satu tempat kegiatan yang ada di Desa Paku Alam tepatnya RT 01 Aula

Monumen Perjuangan untuk dilaksanakan kegiatan pengabdian kepada masyarakat.

2. Penyiapan materi pelatihan, buku panduan dan absensi pelaksanaan kegiatan manajemen stres paska bencana banjir

3. Pelaksanaan kegiatan pengabdian kepada masyarakat yang meliputi:

a. Masyarakat yang ada di Desa Paku Alam diajarkan untuk mengkaji tanda dan gejala stres yang dialami menggunakan kuesioner Self 
Repoting Questionnaire-29 (SRQ29).

b. Masyarakat yang ada di Desa Paku Alam diberikan pendidikan kesehatan atau penyuluhan tentang stres dan cara mengelola stres paska banjir

c. Masyarakat yang ada di Desa Paku Alam diberikan pelatihan tentang cara mengelola stres paska banjir. Adapun tehnik manajemen stres yang diajarkan kepada masyarakat yang ada di Masyarakat yang ada di Desa Paku Alam antara lain:

1) Latihan nafas dalam

$\begin{array}{ccr}\text { Latihan } & \text { nafas } & \text { dalam } \\ \text { dilakukan } & \text { dengan } & \text { cara }\end{array}$
mengambil posis yang nyaman bisa duduk atau tiduran, tutup mata, Tarik nafas dalam dari hidung ditahan sebentar (3-5 detik) kemudian hembuskan udara perlahan-lahan dari mulut, ulangi 4 sampai 5 kali, evaluasi manfaatnya, dan latih secara rutin 3 sampai 4 kali sehari.

2) Latihan relaksasi otot progresif Relaksasi otot progresif adalah latihan mengencangkan dan mengendorkan otot sambal nafas dalam pada otot muka sampai dengan kaki.

3) Latihan berfokus pada lima jari Latihan berfokus pada lima jari dikenal juga dengan hipnotis lima jari, pasien diminta memfokuskan pandangan dan pikiran pada ke lima jari (jari jempol bertemu dengan jari telunjuk, jari jempol bertemu dengan jari tengah, jari jempok bertemu dengan jari manis dan jari jempol bertemu dengan jarik kelingking), tarik nafas dalam, rileks dan kosongkan pikiran.

4) Membangun spiritual positif Melaksanakan ibadah bersama di rumah dengansemua anggota keluarga. Berdoa untuk diri sendiri dan keluarga, masyarakat, tenaga kesehatan dan pemerintah, senantiasa membaca kitab suci dan perbanyak membaca bukubuku agama

d. Masyarakat yang ada di Desa Paku Alam diberikan buku pedoman sebagai acuan untuk pelaksanaan 
kegiatan manajemen stres paska bencana.

Pelaksanaan kegiatan Pengabdian Kepada Masyarakat dihadiri oleh 25 masyarakat Desa Paku Alam Kecamatan Sungai Tabuk 2. Masyarakat diberikan dan diminta untuk mengisi Self Repoting Questionnaire-29 (SRQ-29), yang digunakan untuk mengkaji tanda dan gejala stres paska bencana banjir. Self Reporting Quetionnaire 29 (SRQ 29) merupakan kuesioner yang dikembangkan oleh World Health Organization (WHO) sebagai alat ukur adanya masalah/gangguan jiwa. SRQ 29 berisi 29 pertanyaan yang berhubungan dengan masalah gangguan mental emosional, psikotik, penggunaan Napza dan PTSD yang mungkin mengganggu selama 30 hari terakhir. Setiap gangguan yang ditemukan sebaiknya segera dilakukan intervensi untuk mengatasinya.

Berdasarkan hasil Self Reporting Quetionnaire 29 (SRQ 29), diketahui bahwa sebagian besar masyarakat Desa Paku Alam yang mengalami kecemasan ataupun keluhan somatic (90\%), mengalami psikotik akut (3\%) dan mengalami PTSD (7\%). Gangguan mental emosional ditegakkan jika seseorang mengalami 5 keluhan atau lebih (YA) dari pertanyaan 1 sampai 20 atau mengalami salah satu keluhan dari pertanyaan 21 sampai 29.
Stres bisa dialami oleh setiap orang di dalam kehidupan sehari-hari dan penyebabnya sangat bervariasi, dalam hal ini sebagian besar disebakan oleh situasi paska bencana banjir. Stres yang dialami tersebut dapat menimbulkan gangguan mental emosional seperti ansietas atau kecemasan.

Ansietas adalah perasaan cemas terhadap hal yang penyebabnya tidak jelas atau tidak diketahui secara pasti. Ansietas terdiri dari beberapa tahapan antara lain ansietas ringan, ansietas sedang, ansietas berat dan panik (Stuart, Keliat, Pasaribu, 2016). Dalam kehidupan sehari -hati, pada umumnya individu mengalami ansietas ringan. Ansietas ringan tergolong baik dialami oleh seseorang, oleh karena dapat memberikan motivasi untuk menyelesaikan target yang perlu dicapai atau meyelesaikan masalah yang sedang dihadapi. Seseorang yang mengalami ansietas ringan menunjukkan tanda dan gejala antara lain jantung berdebar-debar, sakit kepala, sampai dengan terjadi peningkatan tekanan darah. Gejala yang disampaikan oleh masyarakat ini didukung oleh teori tentang level ansietas, yang mana terdapat empat level ansietas dengan gejalanya yang berbeda-beda mulai dari ansietas ringan, sedang, berat sampai dengan panik. 
Ansietas ringan merupakan ansietas yang biasanya dialami saat terjadi ketegangan hidup sehari-hari. Ansietas ringan memberikan dampak yang baik bagi seseorang karena dapat memberikan motivasi dan mencegah individu mengalami suatu masalah. Ansietas sedang terjadi oleh karena ketegangan yang lebih berat lagi. Ansietas sedang membuat individu menajdi hanya berfokus pada hal yang sangat penting saja. Ansietas sedang membuat individu menjadi kurang perhatian terhadap apa yang ia lihat dan dengar. Tanda dan gejala fisik yang menyertai pada tingkatan ini seperti banyak berkeringat, merasa gelisah, mondar-mandir serta wajah tampak pucat.

Tingkatan selanjutnya yaitu ansietas berat. Individu yang mengalami ansietas berat mengalami penurunan pada kemampuan mempersepsikan sesuatu. Ketika berada pada ansietas berat, seseorang perlu bantuan untuk dapat fokus berpikir.Tahap yang paling tinggi dari ansietas yaitu tahapan panik. Kondisi panik berkaitan dengan rasa takut dan teror. Individu yang berada pada tahap ini tidak dapat melakukan hal apapun meskipun dengan diberikan arahan. Terjadi penurunan kemampuan dalam berhubungan dengan orang lain. Terdapat peningkatan aktivitas motorik seperti gemetar dan sebagainya.
Tubuh pun memberikan respon terhadap kondisi panik ini, terjadi peningkatan tekanan darah dan tanda-tanda vital yang lainnya (Stuart, Keliat, Pasaribu, 2019).

Pengelolaan stres dan ansietas masyarakat yang diajarkan yaitu latihan napas dalam, latihan relaksasi otot progresif, latihan berfokus pada lima jari, dan membangun spiritual positif. Cara mengelola stres ini dapat dilakukan secara mandiri oleh masyarakat ketika sedang berada pada kondisi stres dan ansietas.

\section{Latihan Relaksasi Napas Dalam}

Latihan relaksasi napas dalam efektif dalam menurunkan tingkat stres pada individu. Latihan relaksasi napas dalam juga diaplikasikan pada beberapa teknik manajemen stres seperti latihan berfokus pada 5 jari dan relaksasi otot progresif. Terdapat perubahan psiko-fisiologi pada tubuh dengan melakukan teknik relaksasi napas dalam. Teknik bernapas lambat mempengaruhi sistem saraf pusat dan otonom yang secara khusus berdampak terhadap jantung dan paru-paru (Creswell et al., 2014). Bila dikaitkan dengan tingkat stres dan ansietas, latihan relaksasi napas dalam hanya bisa diterapkan pada stres dengan kategori tingkatan ringan sampai sedang. 
Setelah dijelaskan tentang cara melakukan latihan napas dalam, tim meminta masyarakat untuk mengulangi kembali tahapan teknik relaksasi napas dalam. Semua masyarakat tampak mampu mempraktikkan teknik latihan napas dalam dengan baik sesuai dengan tahapan yang diajarkan.

\section{Relaksasi Otot Progresif}

Teknik manajemen stres dan ansietas lainnya yang diajarkan yaitu latihan relaksasi otot progresif. Relaksasi otot progresif diajarkan pada masyarakat karena dapat dilakukan secara mandiri, kapan pun dan dimanapun seseorang berada. Relaksasi otot progresif tidak memerlukan peralatan tertentu dalam pengaplikasiannya, individu hanya menggunakan dirinya sendiri. Teknik ini dilakukan dari otot wajah hingga otot kaki. Otot area tertentu dikontraksikan sembari individu menarik napas dalam, kemudian otot di relaksasikan bersamaan dengan napas dihembuskan melalui mulut secara perlahan. Relaksasi otot progresif telah diteliti dapat menurunkan tingkat stres pada individu (Maghfirah, Sudiana, \& Widyawati, 2015). Penelitian lainnya yang juga meneliti tentang relaksasi otot progresif memberikan hasil bahwa terdapat pengaruh yang signifikan antara pemberian terapi dengan tingkat depresi (Alfiyanti, Setyawan, Kusuma, 2014).

Relaksasi otot progresif dilakukan pada beberapa area meliputi area wajah, leher, punggung, anggota gerak atas, anggota gerak bawah. Ketika mempraktikkan latihan relaksasi otot progresif, masyarakat kembali mempraktikan teknik relaksasi napas dalam.

\section{Latihan Fokus 5 Jari}

Teknik selanjutnya yang digunakan untuk menurunkan tingkat stres dan ansietas yaitu latihan berfokus pada lima jari. Latihan berfokus pad lima jari juga dapat digunakan untuk menurunkan ansietas. Teknik ini membutuhkan seorang pemandu untuk mengarahkan individu dalam membayangkan hal-hal yang menyenangkan.

Teknik ini baik digunakan untuk individu yang sehat maupun yang memiliki gangguan fisik dan sedang mengalami ansietas. Satu penelitian membuktikan bahwa latihan berfokus pada lima jari dapat menurunkan tingkat ansietas pada pasien dengan masalah fisik baik yang baru pertama kali dirawat di rumah sakit maupun klien yang sudah pernah dirawat sebelumnya di rumah sakit (Rizkiya \& Susanti, 2017).

Saat pelaksanaan latihan berfokus pada lima jari, masyarakat yang diajarkan teknik ini dapat mengikuti arahan dari pemandu 
dengan baik. Saat melakukan latihan ini, tim membuat suasana yang tenang dalam melaksanakan latihan berfokus pada lima jari ini.

Masyarakat diminta untuk menutup mata, sambal mengatur napas. Kemudian dengan dipandu oleh penyuluh, masyarakat diminta untuk membayangkan: tempat yang paling membuatnya merasa nyaman, membayangkan bila ia berada pada kondisi tertentu dimana merasa sangat sehat, membayangkan pencapaian yang pernah ia alami sehingga ia merasa sangat bangga, serta diminta membayangkan orang yang paling berarti di dalam hidupnya. Penggunaan latihan berfokus pada lima jari ini akan lebih efektif apabila dilakukan dengan kolaborasi teknik relaksasi napas dalam.

Hal ini didukung oleh sebuah penelitian yang menyebutkan bahwa terdapat penurunan ansietas pada pasien dengan penyakit fisik yang diberikan treatment relaksasi napas dalam serta hipnosis lima jari (Febrina \& Malfasari, 2018).

\section{Spiritual Positif}

Melaksanakan ibadah bersama di rumah dengan semua anggota keluarga. Berdoa untuk diri sendiri dan keluarga, masyarakat, tenaga kesehatan dan pemerintah, senantiasa membaca kitab suci dan perbanyak membaca buku-buku agama merupakan cara-cara yang bisa menjadi pilihan masyarakat untuk mengatasi stres dan kecemasan yang dialami.

Kegiatan latihan manajemen stres diakhiri dengan memberikan buku panduan pelaksanaan kegiatan manajemen stres yang bisa digunakan oleh masyarakat Desa Paku Alam sebagai acuan pengelolaan stres ataupun kecemasan paska banjir.

\section{KESIMPULAN}

Kegiatan pengabdian kepada masyarakat yang dilaksanakan dengan metode penyuluhan dan simulasi pelatihan pengelolaan stres dan kecemasan masyarakat Desa Paku Alam Kecamatan Sungai Tabuk berhasil memberian dampak positif dan perubahan tingkat pengetahuan terkait kesehatan jiwa, stres, kecemasan serta cara penanganannya yang telah tim ajarkan berupa berupa latihan napas dalam, latihan relaksasi otot progresif, latihan berfokus pada lima jari, dan membangun spiritual positif.

Diharapkan masyarakat dapat menerapkan cara-cara yang sudah diajarkan secara mandiri sehingga terbangun masyarakat yang sehat jiwa. 


\section{DAFTAR PUSTAKA}

Alfiyanti, N. E. et al. (2014) 'Pada Pasien Gagal Ginjal Kronik Yang Menjalani Hemodialisis Di', Jurnal Ilmu Keperawatan dan Kebidanan (JIKK), 000, pp. 210-221.

Keliat, B.A, Marliana, T. (2018). Dukungan Kesehatan Jiwa dan Psikososial (Mental Health and Psycho Social Support ): Keperawatan Jiwa. Jakarta: ISBN: 978-602-1238-51-6.

Keliat, B.A, Hamid, A. Y. S, Putri, Y. S. E, Daulima, N. H. C, Wardani, I. Y, Susanti, H, Hargiana, G, \& Panjaitan, R. U. (2019). Asuhan Keperawatan Jiwa. Jakarta: Penerbit Buku Kedokteran, EGC.

Keliat, B.A, Marliana, T, Windarwati, H. W, Mubin, M. F, Sodikin, M. A, Prawiro, A. D, Trihadi, D, \& Kembaren, L. (2020). Dukungan Kesehatan Jiwa dan Psiko Sosial (Mental Health and Psycho Social Support) COVID-19: Keperawatan Jiwa. Jakarta: ISBN: dalam proses.

Maghfirah, S., Sudiana, I. K. and Widyawati, I. Y. (2015) 'Relaksasi Otot Progresif Terhadap Stres Psikologis
Dan Perilaku Perawatan Diri Pasien Diabetes Mellitus Tipe 2', Jurnal Kesehatan Masyarakat, 10(2), p. 137. doi: 10.15294/kemas.v10i2.3374.

Marsha, G. C., Diponegoro, A. M. and Utomo, U. H. N. (2020) 'Psychological Well-Being Masyarakat yang Terdampak Banjir : Studi Kasus di Kecamatan Bati-Bati', Prosiding Seminar Nasional Magister Psikologi Universitas Ahmad Dahlan, pp. 1-7. Available at: http://ppjp.unlam.ac.id/journal/inde x.php/jpg.

Taufiq, R. et al. (2014) 'Gambaran Resiliensi Anak Pasca Bencana Banjir di Desa Dayeuhkolot, Kabupaten Bandung, Jawa Barat', Wacana Jurnal Psikologi, 6(11), pp. 73-87.

Parker G, Lie D, Siskind DJ, Martin-Khan M, Raphael B, Crompton D (2016). Mental health implications for older adults after natural disasters - A systematic review and metaanalysis. Int Psychogeriatrics. 28(1):11-20. 